\title{
THE USE OF SLANG AMONG AMERICAN YOUTHS AS RELATED TO THE RISE OF HIP HOP CULTURE: A SOCIOLINGUISTICS ANALYSIS
}

\author{
Niken Fatma Putri ${ }^{1}$, Fauzia ${ }^{2}$ \\ ${ }^{1}$ Universitas Ahmad Dahlan, Indonesia \\ ${ }^{1}$ putriniken30@gmail.com \\ ${ }^{2}$ Universitas Ahmad Dahlan, Indonesia \\ ${ }^{2}$ fauzia@pbi.uad.ac.id
}

\begin{abstract}
This article entitled "The Use of Slang among American Youths as Related to The rise of Hip Hop Culture: A Sociolinguistics Analysis". This research focuses on the types of slang commonly used by American youths and the influence of hip hop on slang use among American youths.

This research belongs to descriptive qualitative research as a method. The subject of this research is rap song lyrics, utterances in slang in America YouTube video and Ellen Show: On Fleek Episode as well as the Urban Dictionary slangs. Then, the objects of this research are the use of slang. The researcher collected the data through the utterances in the rap song lyrics, movie and video, and also slangs in Urban Dictionary.

The results of this analysis show that the type of slang used among American youths are divided into two types. They are based on use and word formation. Meanwhile the use of slang among American youths is related to the rise of hip hop culture influence which brought by some of rap song. The slang contained in rap song lyrics are spread easily by the massive consumption of social media and enlighten highly by the report of conventional media.
\end{abstract}

Keywords: slang, hip hop, American youths

\section{INTRODUCTION}

The dynamic life of USsociety currently becomes a big hit to the changes of world trending topic. It covers all layers. As the leading country in the world, its changes must impact to worldwide from its economic system, politic, culture, social life, even its language. "Language is a product of society, as society's changes so does its languages" (Price: 2007). Language is dynamic, as it is impossible for languages to stick in one lexical term or semantic lexical can be changed, modified or even disappeared from time to time.

The raising culture in U.S currently is hip hop culture that brings the fresh way for youths or people to express themselves. The odd terms they used as another word to express a deeper meaning related to their daily life.The writer found that there is a significant changes of language in term of its use, especially the slang words attached in hip hop song or among members of hip hop communities. The hip hop culture, where freedom becomes the main idea, expresses the creativity and the uniqueness of the culture get overwhelemed consumed by societies (Rockers: 2010). There is a relation between the changes of slang words and youths in American daily life.

This study aims to prove the types of slang commonly used among American youths and the influence of hip-hop culture to the use of slang among American youths. Several researches were done in theses written by previous scholar of English Education Department in Universitas Ahmad Dahlan. A descriptive study of American Slang in 2 Fast 2 Furious had been discussed by Solichin in 2007. Acomparative study between American and Australian Slang had been explained by 
Handoko in 2016. The studies of slang words in $20^{\text {th }}$ century had been discussed generally by Khachatryan in 2016. The sociolinguistic studies of American slang also had been discussed by Zhou in 2013. The creation of students' academic slang word in university was discussed already as well by Arua in 2013. The studies of hip hop affect English was slightly discussed by Price in 2007.

The difference of this study from previous studies are that the writer is going to discuss the latest or the updated version of slang among Americans and also the relation of the rise of hip hop culture among american youths to the use of slang in their daily life.

\section{LITERATURE REVIEW}

2.1 Slang and Its Relation to Sociolinguistics

Eble (1996:11), stresses that the social and interpersonal aspects of slang and its functions, "To establish or reinforces social identity or cohesiveness within a group preserve group solidarity". Thus slang used to show social identity of certain group, focusing on American youths to express solidarity or telling same understanding about something to one another.

According Kipfer and Robert, (2008), "slang is especially notorious". Thus slang is famous by its use related to negative issue, whether to describe black phenomenon or used by people inside of pressuring circumstances, like happened in black American youths. As stated in drake's song the word "yolo" refers to you only live once is too influencing toward youths currently, it reflects the youths dynamic psychology when the character is trying to find the real themselves and demand for happiness and freedom.

The characters of sociolinguistics theory is that it tends to examine the effect of society on language, According to mlc.linguistics.georgetown.edu, (2016), "Sociolinguistics is the study of how people use language in their everyday lives. Sociolinguistics looks at how identities are manifested through the words we use and how, through language, we (intentionally or unintentionally) create, maintain, and disrupt relationships with others". Thus it makes the study that writer wants to elaborate in this thesis is important to be discussed in linguistics. And this study should be categorized as the sociolinguistics analysis as it examines the effect of society to language.

2.2 The Slang Theories related to Youths

According to Wills (1995) For the most part, Slang is the result of linguistics inventiveness, especially of young and lively persons who want fresh, original pungent or racy terms with which they can rename ideas, actions, and objects that they feel strongly about. In effect slang is the result of a combination of linguistics irreverence and reaction against staid, stuffy, pompous, pretentious, colorless direction Thus, related to Wills' statement, slang is used by people or community who feel lively and freely live, in order to break the honorific norm like commonly used by common people. The system of slang may change the form, meaning, or rename the object in order to stand again the strict or classy terms commonly used by people outside the group. It purposes to redirect people mindset about race, ethnic, and such.

In conclusion based on theories above, Slang is very related to the life of youths, since they are the ones who eagerly seek for their identity, demands the up to dated things, and have a lively life, even slang is non-standard language that informally spoken by certain layer of society especially youths to remark their era and reinforce their identity as youths. 


\subsection{Types of Slang}

In this part the writer will only explain about several kinds of slang which related to American slang used by youths attached in hip hop songs as accordance to Patridge (1950) classification.

\subsubsection{Cockney Slang}

It is a form of English which originated in the east end of London and has been popularized by film, music, and literature, for example Anthony Burges who used rhyming slang as a part of fictious dialect in his classic book, A Clockwork Orange. The Construction of Rhyming slang involves replacing a common word with a phrase of two or more words, omitting a word of two or more is almost done in all cases, as a result the secondary rhyming or after implied that shows totally different form from the originated words make the meaning or phrase elusive to the listeners not in the aim to know.

\subsubsection{Society slang}

Every social group uses some types of slang and by association those words and grammar become the property of that group, aim to define them in certain way. In the modern world, slang has become so much defining trait of so many groups that it is impossible to ignore the impact attached in western society. Unfortunately the impact results to the underscoring social and class separations. According to Patridge (1950), the writer concludes that, slang is depend on the dynamicity of life or universe. It is progressive and contingent upon the class, group, or circumstances. It might be in the form of calling or honorific term but it's too rare to see slang used to describe a respect call. It is often used to express the amusement upon certain group toward someone or something that might portray the activity surround.

\subsubsection{Slang in Public School and university}

It comes from student's expression as the main source, as they are youths they are fresh, full of spirit. It is identical based on school circumstances, one school might have different type of slang to another. Meanwhile, university slang is different to public school slang. It is identical to their phase or their era, based on university identity, i.e. Colombia University has different identity as Canada University. Speakers are habituated to speak bluntly in their university conversation and renewing the past slangs to the fresher one.

Meanwhile According to Chapman (1998), there are two types of slang, they are primary and secondary

\section{a. Primary slang}

It is a pristine speech of subculture members; it is also natural to its speakers that seems they might be mute without it. Slang is by definitions always refers to alternative idiom to be chosen rather than required. Much of teenage talk and the speech of urban street gangs would be the examples of primary slang. Primary slang can be detected by contrast, their oral language is often rich, complex, powerful, and they live by using it effectively which Chapman (1988) calls the specialized social vocabulary of subculture primary slang. The primary slang of groups is often appropriated into general slang. It hits members of the mainstream as novels which are rich in imaginative things or song with fresher and wilder expressions in its lyric. It suggests a way of life with greater fun and excitement than the well - regulated most lives served.

b. Secondary Slang

This type of slang is chosen not so much to fix one group to express one's attitudes and resourcefulness by pretending momentarily hence to express 
someone's contempt, superiority, cleverness by borrowing someone's verbal dress. It is also the matter of stylistic choice rather than true identification. It's secretly expressed in certain group of society. Like in certain office or institutions, where mostly only its members who notice the meaning.

2.4 The slang formation

Slang is a product of word formation there are several formation that slang need to pass by to be as it is. The writer will show several step based on linguist' study about slang word formation. According to Mattielo (2008), citied in his book "Introduction to English Slang", that word formations used to develop slang, some of them are: Acronym and Initialism; Elliptic Rhyming Slang; Variations; Word Manufacture and fanciful Formations; Prefixation; suffixation and Conversion

Meanwhile, According to Zore (1993) cited in Rahmawati A (2012), word formations used to pump up the creativity in making slang are Clipped Word; Compounding and some.

2.5 The development of hip hop linguistics and its relation to urban youth

According to Vygotsky, (1930), Thought is later influenced by language. It proves on how strong that language could change human's behavior, started from its thought. It's possible that language could influence a culture. It is related to the language or its linguistics. Where culture is coming from thought or people's view that expressed by certain language. As citied by Howe, (2006) People tend to assume that hip hop words is illogical and ungrammatical, but there is a system there and a grammar that can be described. Rap music may be ear torture for many people, but for linguists, this is an illumination. The development of hip hop linguistics is complex. According to Wikipedia (2014) Source material include the spirituals of slaves arriving in the new world, Jamaican dub music, the laments of jazz and blues singers, patterned cockney slang and radio deejays hyping their audience in rhyme. Hip hop has a distinctive associated slang. It is also known by alternate names, such as "Black English", or "Ebonics". Academics suggest its development stems from a rejection of the racial hierarchy of language, which held "White English" as the superior form of educated speech. Due to hip hop's commercial success in the late nineties and early $21^{\text {st }}$ century, many of these words have been assimilated into the cultural discourse of several different dialects across America and the world and even to non-hip hop fans. Elliot's poem ever stated that hip hop culture has potential to change social culture and its language is one of the gun shot. The various words that has connotation meaning such as milkshake means sexy girl, desert means attractive girl and such are the symbol when the semantic shift is also happened to hip hop linguistics from the original meaning of English.

\section{METHODS}

3.1 Types of Research

This study belongs to qualitative research because this study does not use numerical data and any statistic. The writer will use descriptive researches since the writer will analyze the relation of the use of slang words among American youths and its relation to the rise of hip hop culture. And also the result of this study is descriptive. It will describe the use of slang among American youths and its relations to the influence of hip hop culture.

3.2 Research Subject, Object and Data

The research subject is the videos contains of conversation among youths in ghetto area, words in urban dictionary as well as the music videos of rap song. The research objects of this study are the calling terms used by youths to their peer as 
well as the phrases that commonly used as naming one specific actions. Data can be called as sample. It is something that will be observed. Data is based on the research object and will be taken from research subject. The transcription of videos whether the lyrics or the conversation as well as the slang attached in urban dictionary.

3.3 Method and Technique for Collecting Data

The writer will use simak method as the method of collecting data since the writer will observe the data that belongs to written and spoken language. The data of this study is slang words use in daily activities among American youths or rap song lyrics Therefore, the writer will use catat (noting) techniques for collecting data. The procedures of collecting data are:

3.4 Method and Technique for Analyzing Data

In this study, the writer will use Padan Extralingua method for analyzing data method. It is because the determined device of this study is from the extrinsic aspect of the languages that will be analyzed. It means the writer will analyze the use of the term, its speaker, its receiver, and its relation to environment surround, or Hip hop culture.

\section{FINDINGS AND DISCUSSION}

4.1 Types of Slang among Commonly Used among American Youths

The writer will divide the types into two types of slang. The first one is based on use and the second one is based on the word formation.

\subsubsection{Based on The Use}

a. Cockney Slang

This slang aims to create good rhyme of speaking and suitable analogy. This is the table to shown further common examples of this kind of phrase

Table 1. The List of Cockney Slang

\begin{tabular}{|l|l|l|l|}
\hline Slang & Meaning & Original Phrase & The Reason \\
\hline Dog & Telephone & Dog-and-bone & $\begin{array}{l}\text { The speakers in a } \\
\text { phone looks like } \\
\text { catching and bark to } \\
\text { one another. It's an } \\
\text { analogy. When the } \\
\text { omission bone makes } \\
\text { it drop and dog as the } \\
\text { spoken slang }\end{array}$ \\
\hline
\end{tabular}

b. Slang In Society

The slang used to describe an activity or express certain feelings of society to describe someone or something.

Table 2. The List of Slang in Society Widely Known as Hip Hop Song

\begin{tabular}{|l|l|l|}
\hline Slang & Meaning & The way it used \\
\hline Hip & $\begin{array}{l}\text { Super cool, currently the } \\
\text { word super is rare to be } \\
\text { used }\end{array}$ & $\begin{array}{l}\text { "check out the party downtown instead it's gonna } \\
\text { be hip" stated in Urban Dictionary (2003) }\end{array}$ \\
\hline Dope & $\begin{array}{l}\text { Cool, successfully done } \\
\text { something }\end{array}$ & $\begin{array}{l}\text { "I'm the dope man." stated in Dope Man Pushin' } \\
\text { lyric by Scarface it Papa Reu (2015) }\end{array}$ \\
\hline Bounce & $\begin{array}{l}\text { Run or Escape, in order to } \\
\text { avoid someone or } \\
\text { something }\end{array}$ & $\begin{array}{l}\text { "that he bounce from cops this morning" Video, } \\
\text { Slang in America, Source: youtube/video (2013) }\end{array}$ \\
\hline
\end{tabular}


c. Slang in University and Public School

As stated in theoretical framework, it's progressive slang type. It's based on certain student era and its own circumstances. But here, the writer will try to summarize by choosing most common slang used by American students.

Table 3. The List of Slang Used By Public School Student in America

\begin{tabular}{|l|l|l|}
\hline Slang & Meaning & The Implementation in the context \\
\hline Savage & $\begin{array}{l}\text { Refers to badass who crazily } \\
\text { blunt to or straight up }\end{array}$ & $\begin{array}{l}\text { "my ex-girlfriend called me last night but I told her } \\
\text { to } \mathrm{f}^{* * *} \text { off" "dude you're savage" stated by } \\
\text { @Mirve in a native group chat , HiNative.com, } \\
2016\end{array}$ \\
\hline Flexing & $\begin{array}{l}\text { Overly show off his money and } \\
\text { intimidating. Huffington.ca. } \\
2017\end{array}$ & $\begin{array}{l}\text { I knew him, He's totally flexing, adapted from } \\
\text { huffington.ca, a Canadian teens trend report 2017 }\end{array}$ \\
\hline
\end{tabular}

Now, the writer will deal to the phrases or slang words that commonly used in U.S University that related to a discussion among higher students or their call term to fellas or lecturer. Those slangs are adapted from Share America article written by trainer (2015) published by official website of American Government to publish daily activities or language used by American.

Table 4. The list of Slang Used by American Higher student.

\begin{tabular}{|l|l|l|}
\hline Slang & Meaning & In Conversation \\
\hline GPA Killer & A very hard class to be passed & $\begin{array}{l}\text { I know I should take that class, but } \\
\text { it's going to be A GPA killer }\end{array}$ \\
\hline Ace & To get best grade as possible & $\begin{array}{l}\text { All that studying I did paid off. I } \\
\text { aced the exam }\end{array}$ \\
\hline
\end{tabular}

\section{d. Primary Slang}

It is a slang that commonly known and is able to be predicted its meaning as it has general form that everyone might consider its intention

Table 5. The List of Primary Slang that Attached in Daily Youth's Conversation or Hip Hop Song Lyrics

\begin{tabular}{|c|c|c|}
\hline Slang & Meaning & Contextualization \\
\hline Fo sho' & Derivative from for sure & $\begin{array}{l}\text { "Now, Huh aw fo sho'- fo sho' my bae, } \\
\text { what's cracked with you" Youtube video } \\
\text { Slang in US (2013) }\end{array}$ \\
\hline Bae & $\begin{array}{l}\text { Refers to a call term } \\
\text { baby, to } \\
\begin{array}{l}\text { affection } \\
\text { affow }\end{array}\end{array}$ & $\begin{array}{l}\text { Bae.... It means baby or sweety.....-Ellen } \\
\text { show, On Fleek episode (2015) }\end{array}$ \\
\hline Netflix and Chill & Hook up, or having a sex & $\begin{array}{l}\text { I'm going Netflix and chill. Ellen Show, On } \\
\text { Fleek episode (2015) }\end{array}$ \\
\hline
\end{tabular}

\section{e. Secondary Slang}

It's a slang that be a secret among certain group. Or only particular group that knows the intention of that slang. The data below belong to an article published by TheTab website written by Taylor (2016) by the title The A-Z of LGBT Lingo. 
Table 6. The List of Secondary Slang

\begin{tabular}{|l|l|l|}
\hline Slang & Meaning & Place used \\
\hline Jockstrap & Standard of gay underwear & Among Gay Chat \\
\hline Otter & A young, slim hairy male & Among Gay Chat \\
\hline
\end{tabular}

4.1.2 Types of Slang based on Word Formation

\begin{tabular}{|c|c|c|c|}
\hline No & Slang Formation & Example & Explanation \\
\hline 1 & Compounding & Jive + ass & $\begin{array}{l}\text { Refers to person with } \\
\text { full of excitement. }\end{array}$ \\
\hline 2 & Prefixation & Super + fly & $\begin{array}{l}\text { The prefix super refers } \\
\text { to really or totally }\end{array}$ \\
\hline 3 & suffixation & $\begin{array}{l}\text { Best + ie } \\
\text { Gang +ster } \\
\text { Load + ed }\end{array}$ & $\begin{array}{l}\text { The suffix ie, ster, and } \\
\text { ed used to be as } \\
\text { suffixes to form slang }\end{array}$ \\
\hline 4 & Affixation & Watchin' & $\begin{array}{l}\text { The ' } \mathbf{n} \text { ' is appealed } \\
\text { and inserted to word } \\
\text { watching after the } \\
\text { omission of ' } \mathbf{g} \text { ' }\end{array}$ \\
\hline 5 & Word manufacture and fancifulness & Bounce & $\begin{array}{l}\text { Refers to run and } \\
\text { escape }\end{array}$ \\
\hline 6 & Acronym and initialism & OG & $\begin{array}{l}\text { Original gangster in a } \\
\text { short way. }\end{array}$ \\
\hline 7 & Conversion & Dope & $\begin{array}{l}\text { Refers to adjective } \\
\text { means cool converted } \\
\text { from dope, a noun, } \\
\text { means drug }\end{array}$ \\
\hline
\end{tabular}

4.2 Hip Hop Culture Influences The use of Slang Among American Youths 4.2.1 The American Youths' Social life Portrayals

In 2017 the chosen president Donald Trump perpetuates the hatred among American majority to Mexican by his wall building policy. In the end of Obama administration, the rise of black lives matter become the trending topic for worldwide. The states of pluralism when diversity appreciation become the slogan of United State of America remain questioned. In the other side the rise of Hip Hop culture is the product of society to create an identity and social reinforcement (Britanica:2017). Known as cultural movement. Hip Hop bring the nuance of criticizing the current situation and ride the freedom of speech, the freedom of expression. According to New York Times Journal 2008 most of Teenagers listen to music at least $\mathbf{2 . 5}$ hours per day or more. The writer concludes in a chart about American Youths music preference based on ABC News, A commercial television channel in United States as citied in Linkedlin.com wrote by Gordon Moore (2017), US Sociology Higher student. He showed that $26 \%$ of youths love to listen to Hip hop

4.2.2 American Youths respond to hip hop culture.

In 2015, US Youth Empowerment Organization trough Delpleache, stated that rap song portrayed a fancy life, like glamorous, sex, and wealthy life to the youths. To teens in poor communities rap music tells their sweet escape, even the lyric might speak their current life.

'.... And all those who looked down on me, I'm tearing your balcony'.... And cut the crap..'

A rap song sung by Eeminem in the 'I'm Not afraid' song- 
That piece of lyric depicts the current situation of colored youth or youth as a whole about pressure and prejudice of major toward them, like 'you're black, you're done'. The word 'crap' is slang word which means non sense. The word 'crap' portrays the desperate and pissed life of youth's life in US.

The rise of black as the US president, Barack Obama doesn't redeem all the prejudice and sentiment of major to black. 2017 is still be the year of \#BlackLivesMatter, the happening phenomenon in US about Black fight for their right and against all silent and direct discrimination.

For white youths, the pressure of youth in general is about success in wealth, where nuance of capitalist is that strong to begin with, and be the spirit of the US society. Capitalist is all about competition and anything valued as money speak. The fear and uncertainty of future is commonly felt by youth in general

Rap Song is a fantasy of all sweet escaped for youths and the platform for them to voice out their current psychology resulted from inner or social pressure. Rap language helps them to opt out. The moment the speakers practice the slang it is relatable to youth also reinforce their identity as a fresh and free spirit human being. More than that historical background that slang existences is to break language hierarchy was also be the basic reason why slang is always progressive

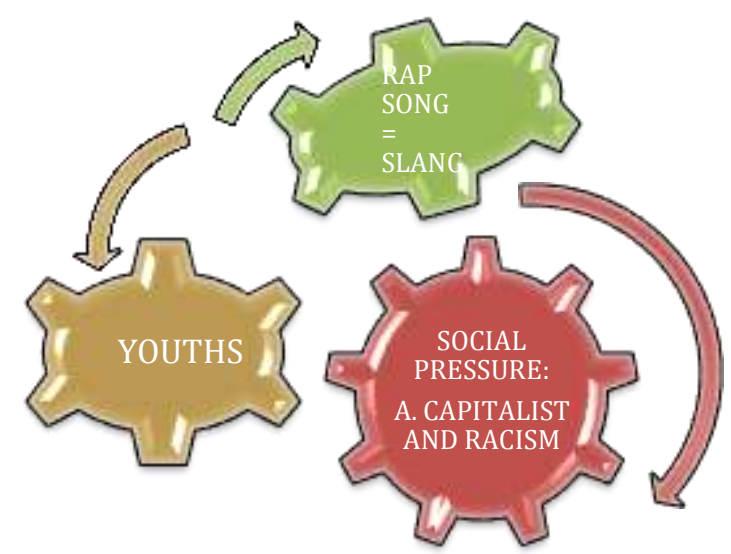

Figure.1. The Smart Graphic of Rap Song Relation to Youths' Social Background

\subsubsection{The Ride For Hip Hop To Influence Youths}

It is important to discuss 'what the platform of hip hop to spread its vibe is' despite the writer already talked a lot about youth's respond to hip hop.

a. Social Media

Social media is the most significant rides for hip hop to spread its vibe. Social media is a strategic platform for people especially youths to express their current mood, to spread the memorable memory, or search the most trending issues in the world. Social media is a media of expression for youths, without limit, filter, or boundaries.

Time significances of gadget use among United States Youths is proven by a report came from Wallace (2015) as reported in CNN news, one of the prominent news company in US, that teens spend 9 hours per day to check on their social media or browse through social media. They search its song trough social media and listen to the beat and try to comprehend the lyric, where slang was glamorized. 
b. Conventional Media

The writer labels conventional media as non-social media broadcast system, such as radio, television, newspaper, or magazine. It is less significant ride for hip hop to spread but this conventional media will help youths unconsciously connect to the vibes of hip hop. The moment youths use social media, it is the moment they have intention and interest to search. But conventional media spread the vibes without classifying the viewers.

The depiction of hip hop culture as current interest of major youths are also be the spotlight of conventional media. Proven trough the report of summer camp in 2016 have hip hop identity as the main icon to attract the participants.
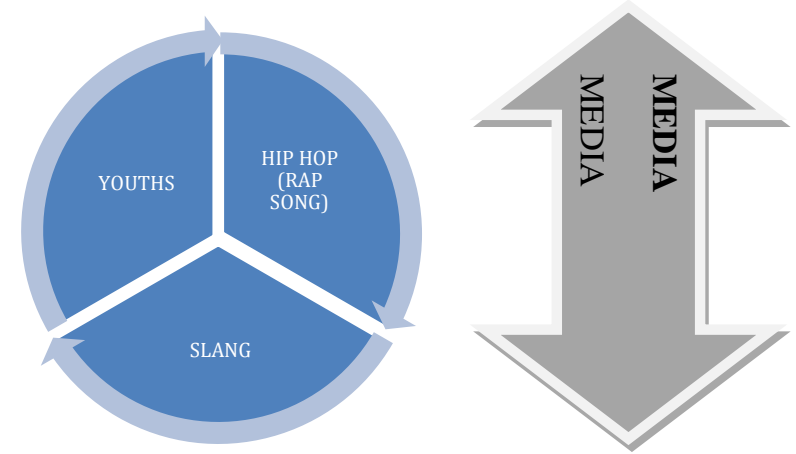

Figure 2. The Process of How Hip Hop Culture Influences American Youths

\section{CONCLUSION}

The slang commonly used among American youths is divided into two types based on its use and word formations. The influence of hip hop upon the use of slang comes from the glamorization of rap song among youth trough social and conventional media. The rap song lyrics contains the essence of slang called as freedom.

\section{REFERENCES}

Arua, AE. \& MM Aimi. (2013). The Creation of Students Academic Slang Expression in the University of Botswana. http://dx.doi.org/10.13092/lo.40.429

Banks, Cherry Mcgee. James A Bank. (2007). Multicultural Education: Issues and Perspective. https://www.amzon.com/Multicultural-EducationEducation-Issues-and-perspective

Cambridge. (2014). Cambridge Dictionary: third edition. Cambridge: Cambridge University

Chapman, Robert L. (1988). American Slang. London: Harper \& Row Publisher Inc

Eble, C Conie. (1996). Slang and Sociability. North Carolina: North Carolina University Press

Handoko, Rudi. (2016). A Comparative Study between American and Australian Slang. Yogyakarta: Universitas Ahmad Dahlan

Howe, M. H.(2006). A sociolinguistics article. Fort Worth: HarcourtBrace Jovanovich College Publishers

Khachatryan, Ani. (2016). American Slang: the 20 th Century. www.academia.edu/151333/American_Slang_the_20th_century 
Kipfer, Barbara Ann and Chapman L Robert. (2008). Dictionary of American slang words. New York, United States: Collins

Mattiello, Elisa. (2008). An Introduction to English Slang. Monza Milano, Italy: Polimetrica, International scientific Publisher

Moore, JayaGordon. (2017). To What Extend can Hip Hop be Blamed for Youth Violance. https://linkedin.com. Accessed on Sunday, June 4th 2017: 09.00 PM

Partridge, Eric. (1950). Slang Today and Yesterday with A Short Historical Sketch: and Vocabularies of English American, and Australian Slang. London: Routledge and Kegan Paul

Peckham, Aaron. (1999). Urban Dictionary: Forth Edition. California: Andrew Mcmeel

Price, Gareth. (2007). Language Society and State: From Colonization to Globalization in Taiwan. Mansfield: United Kingdom Publisher.

Rahmawati, Afifah. (2012). Word Formation of Slang Words Used by Transsexual. Semarang:. Diponegoro University.

Rockers, Jonathan. (2010). Study on Linguistics Anthropology and Archeology. http://Journals.uair.airizona.edu

Solichin, Rachmat Dean. (2007). A Descriptive Study of American Slang in 2 Fast 2 Furious. Yogayakarta: Universitas Ahmad Dahlan

Sudaryanto. (1993). Metode dan Aneka Teknik Pennelitian Wahana Kebudayaan Secara Linguistic. Yogayakarta: Duta wacana Univeristy Press.

Taylor, Liam. (2016). The A-Z of LGBT Lingo. http://TheTab.com/The/LGBT/Lingo

Trainer, Mark. (2015). Talking The Collage Talk. https://www.sahre.america.gov/talking/the/collage/talk.

Vygotsky Lev.S. (1930). The Socialist Alteration of Man. Accessed in www.Marxistsfr.org/The_Socialist_aaalteration_of_Manhttp://scholar.go ogle.Linguistik.Online.Journal

Wallace, Kelly. (2015). Teens spend a 'mind boggling' 9 hours a day using media, report says. www.cnn.com/2015/11/03/health/teen.

Wills, David. (1995). Prosthesis. Stanford: Stanford University Press

Zaru, Deena. (2017). Joe Badass: How Hip Hop is evolving in the Age of Trump http://edition.cnn.com/2017/04/14/politics/joey-badass-album-allamerikkan-badass-hip-hop/index.htm

Zhou Y, A. (2013). Sociolinguistics Study of American Slang. Finland: Academy Publisher.

https://mlc.linguistics.georgetown.edu/about-sociolinguistics/what-issociolinguistics-2/on Tuesday, June 6th 2017: 11.30 PM Accessed

https://www.britannica.com/topic/hiphop.Accessed on Monday, June 5th 2017: 09.00 PM

www.mobile.nytimes.com/new-york-today-the-home-of-hip-hopAccessed on Tuesday, June 6th 2017: 09.00 PM

www.cnn.com/DonaldTrump/mocks/hiphop/as/talking/CNNpolitics . Accessed on Monday, June5th 2017: 10.00 PM

www.wikipedia.com/history/of/hip-hop/development . Accessed on Tuesday, June 6th 2017: 10.00 PM 
www.livebinders.com/Spinditty_Hiphop_marketing_strategy Accessed on Monday, June 5th 2017: 10.00 PM http://www.huffingtonpost.ca/2016/12/16/slang-words-

2016_n_13608230.html. Accessed on Tuesday, June 56h 2017: 10.00 $\mathrm{PM}$ 